\title{
The effects of diets enriched in omega-3 fatty acids on carcass characteristics and the fatty acid profile of intramuscular and subcutaneous fat in pigs ${ }^{*}$
}

\author{
M. Wojtasik ${ }^{1}$, S. Raj, G. Skiba, D. Weremko and M. Czauderna \\ The Kielanowski Institute of Animal Physiology and Nutrition, Polish Academy of Sciences, \\ Department of Protein and Energy Metabolism \\ 05-110 Jabłonna, Poland
}

(Received 2 August 2012; revised version 6 November; accepted 15 November 2012)

\section{ABSTRACT}

The objective of this study was to determine the effect of the concentration of C18:3 n-3 and the total concentration of polyunsaturated fatty acids (PUFA) and n-3 PUFA in the diet on the performance of pigs, carcass characteristics, and fatty acid profile of intramuscular fat of Musculus longissimus dorsi (MLD) and subcutaneous tissue (ST) fat. Twenty-four crossbred pigs ${ }^{\top}$ Duroc $\mathrm{x}$ O (Polish Large White x Danish Landrace) were divided into 3 groups (A, B, and C) and from 60 to $105 \mathrm{~kg}$ body weight (BW) were fed isoenergetic (average $13.5 \mathrm{ME} \mathrm{MJ} \mathrm{kg}{ }^{-1}$ ) and isolysinic (average $7.4 \mathrm{~g} \mathrm{~kg}^{-1}$ standardized ileal digestible lysine) diets in which $10 \%$ of the metabolizable energy had been replaced by fat mixtures totaling 3.5\% per $\mathrm{kg}$ diet. Diet A contained 1\% rapeseed oil, $2 \%$ fish oil, and $0.5 \%$ lard; diet B contained 2.5\% rapeseed oil and 1\% linseed oil; and diet C contained 2.5\% linseed oil and $1 \%$ fish oil. The diets had similar amounts of C18:2 n-6, but differed in the amounts of C18:3 n-3 (ALA), 20:5 n-3 (EPA), and 22:6 n-3 (DHA).

Fat mixtures in the diet did not influence growth, carcass performance, lipid or fatty acid concentrations in the tissues of the pigs, but changed their PUFA concentration. ST fat compared with MLD fat had a higher $(\mathrm{P}<0.01)$ ratio of both PUFA/SFA $(0.61$ and 0.38 vs 0.74 and 0.32 vs 0.77 and 0.41, respectively, in groups A, B, and C) and PUFA n-6/n-3 PUFA ( 9.0 and 4.45 vs 6.18 and 3.82 vs 3.99 and 3.51, respectively, in groups A, B and C). Meat and fat from pigs of group C had PUFA/SFA and PUFA n-6/n-3 PUFA values consistent with WHO recommendations. Thus, it can be concluded that supplementation of the diet for pigs with a mixture of linseed oil and fish oil makes it possible to obtain good quality pork with health-promoting properties.

\footnotetext{
* Supported by the Project BIOFOOD - Innovative. Functional Products of Animal Origin, No. POIG.01.01.02-014-090/09 co-financed by the European Union from the European Regional Development Fund within the Innovative Economy Operational Programme 2007-2013

${ }^{1}$ Corresponding author: e-mail: m.wojtasik@ifzz.pan.pl
} 
KEY WORDS: pigs, carcass, fatty acid profile, Musculus longissimus dorsi, subcutaneous fat

\section{INTRODUCTION}

The fatty acid composition of meat has long been studied but still receives much attention due to its implications for human health (e.g., Laaksonen et al., 2005). The recommendations of the World Health Organization (WHO/FAO, 2003) resulted in increased interest in meat containing beneficial fatty acids. Natural sources of n-3 polyunsaturated fatty acids (n-3 PUFA), mainly eicosapentaenoic (EPA, 20:5 n-3) and docosahexaenoic (DHA, 22:6 n-3) acids, are marine fish. In Central Europe, however, the consumption of these fatty acids derived from fish is low and traditional eating habits are difficult to change within a population. The consumption of n-3 PUFA from terrestrial animal products is mainly limited to the intake of $\alpha$-linolenic acid (ALA, C18:3 n-3) and very small amounts of EPA and DHA. For this reason, one of the ways to increase consumption of n-3 PUFA is to enrich traditional food products (meat and meat products) in it (Rae's et al., 2004). It is advised to adapt animal feeding strategies to bring the fatty acid composition of terrestrial animal products more in line with the values proposed in the various nutritional recommendations for humans. The quantity and composition of fatty acids in the diet affects the amount and quality of compounds accumulated in the body, the fatty acid profile, and the sensory value of meat (e.g., Kloareg et al., 2007; Flachowsky et al., 2008). Using linseed oil or fish oil in the feeding of pigs makes it possible to modify the chemical composition of the carcass in such way to make it nutritionally beneficial to humans (e.g., Flachowsky et al., 2008; Jaturasitha et al., 2009). In humans, linoleic acid (LA, C18:2 n-6) and ALA are classified as essential fatty acids, i.e., they must be supplied in the diet. The organisms of both humans and pigs are able to metabolize about one-third of dietary ALA to EPA and docosapentaenoic acid (DPA, C22:5 n-3), and to a lesser degree, to DHA (e.g., Kloareg et al., 2007). It was found, however, that LA and ALA as precursors of long-chain PUFA cannot be regarded as the only source of EPA and DHA in the diet. Indeed, as humans age, the capacities of enzymes (elongases, $\Delta 6$ - and $\Delta 5$-desaturases) involved in the biosynthesis of EPA, DPA, and DHA has been found to decrease (Heird and Lapillonne, 2005). For this reason, fish oils are a better source of EPA and DHA and are used to modify the fatty acid profile of the carcass, thereby effectively enhancing pork in long-chain polyunsaturated fatty acids.

Recent literature (e.g., Kloareg et al., 2007; Wood et al., 2008; Więcek et al., 2010) provides data on the relationship between diets enriched in a single vegetable oil (e.g., linseed or rapeseed oil) and the fatty acid profile of pork.

The aim of the current study was to investigate changes in the fatty acid concentration of intramuscular fat in Musculus longissimus dorsi and subcutaneous 
tissue fat in pigs fed from 60 to $105 \mathrm{~kg}$ body weight (BW) diets in which part of the metabolizable energy was replaced by fat mixtures containing different amounts of $\alpha$-linolenic, eicosapentaenoic, and docosahexaenoic acids, but having similar concentrations of linoleic acid. We expected to find an optimal diet composition that most favourably changes the fatty acid profile (n-3 PUFA concentration) and positively influences the ratios of PUFA/SFA, $\Sigma$ n- $6 / \Sigma n-3$ to improve the quality and health-promoting properties of pork.

\section{MATERIAL AND METHODS}

\section{Animals and housing}

The study was carried out on 24 crossbred pigs (barrows: gilts, $1: 1$ ) ${ }^{\lambda}$ Duroc $\mathrm{x}$ P(Polish Large White $\mathrm{x}$ Danish Landrace) grown from 60 to $105 \mathrm{~kg}$ body weght (BW). At $60 \mathrm{~kg} \mathrm{BW}$ the animals were allotted into 3 groups ( $\mathrm{n}=8$ per group) and kept individually in pens $\left(2.6 \mathrm{~m}^{2}\right)$ equipped with nipple drinker, on a concrete floor without straw. Granulated feed was offered dry at a dose of $85 \%$ of ad libitum intake twice a day (at 8.00 and 14.30). The feed allowance was changed weekly according to body weight.

\section{Diets}

The three experimental diets were composed of barley, maize, wheat, soyabean meal, rapeseed meal, and supplemented with a vitamin-mineral mixture enriched with crystalline amino acids. Pigs from 60 to $105 \mathrm{~kg} \mathrm{BW}$ were fed isoenergetic (average 13.5 ME MJ kg-1) and isolysinic (average $7.4 \mathrm{~g}^{-1} \mathrm{~kg}^{-1}$ standardized ileal digestible lysine) diets where $10 \%$ of the metabolizable energy had been replaced by fat mixtures for a total of 3.5\% per kg diet. Diet A contained 1\% rapeseed oil, $2 \%$ fish oil, and $0.5 \%$ lard; diet B contained $2.5 \%$ rapeseed oil and $1 \%$ linseed oil; diet C contained $2.5 \%$ linseed oil and $1.0 \%$ fish oil (Table 1). The experimental diets contained $150 \mathrm{mg} \cdot \mathrm{kg}^{-1}$ of vitamin E to protect PUFAs against auto-oxidation. All diets had practically the same amount of linoleic acid (LA), but differed in the amounts of ALA, EPA, DHA, and the C18:2 n-6/C18:3 n-3 ratio.

\section{Sample collection}

The apparent digestibility of nutrients was determined (on 12 pigs, 4 per group) at approximately $80 \mathrm{~kg} \mathrm{BW}$, applying three-day collection of faeces, using the $\mathrm{Cr}_{2} \mathrm{O}_{3}$ indicator method. At $105 \mathrm{~kg} \mathrm{BW}$ and after $16 \mathrm{~h}$ of starvation, all of the pigs were slaughtered using electrical stunning at the experimental slaughter house of our Institute. After slaughter, the carcass was weighed and chilled for $24 \mathrm{~h}$ at $4^{\circ} \mathrm{C}$. 
Table 1. Ingredients, chemical composition and nutritive value of diets, $\mathrm{gkg}^{-1}$

\begin{tabular}{|c|c|c|c|}
\hline \multirow{2}{*}{ Indices } & \multicolumn{3}{|c|}{ Diet } \\
\hline & A & $\mathrm{B}$ & $\mathrm{C}$ \\
\hline \multicolumn{4}{|l|}{ Ingredients, $\mathrm{g}^{\prime} \mathrm{kg}^{-1}$} \\
\hline barley & 360 & 360 & 360 \\
\hline wheat & 360 & 360 & 360 \\
\hline maize & 100 & 100 & 100 \\
\hline rapeseed meal & 40 & 40 & 40 \\
\hline soyabean meal & 80 & 80 & 80 \\
\hline rapeseed oil & 10 & 25 & - \\
\hline linseed oil & - & 10 & 25 \\
\hline fish oil (cod liver oil) & 20 & - & 10 \\
\hline lard & 5 & - & - \\
\hline premix $^{1}$ & 25 & 25 & 25 \\
\hline \multicolumn{4}{|l|}{ Chemical composition, $\mathrm{gkg}^{-1}$} \\
\hline dry matter & 889 & 892 & 887 \\
\hline ash & 41 & 41 & 41 \\
\hline organic matter & 848 & 851 & 846 \\
\hline crude protein & 167 & 172 & 166 \\
\hline ether extract & 62 & 61 & 64 \\
\hline starch & 453 & 460 & 440 \\
\hline sugar & 83 & 84 & 88 \\
\hline crude fibre & 43 & 40 & 41 \\
\hline \multicolumn{4}{|l|}{ Nutritive value (determined), $\mathrm{g}^{\mathrm{kg}}{ }^{-1}$} \\
\hline digestible crude protein & 134 & 133 & 131 \\
\hline lysine & 74 & 7.4 & 7.4 \\
\hline methionine & 2.63 & 2.63 & 2.63 \\
\hline threonine & 5.00 & 5.00 & 5.00 \\
\hline thryptophan & 1.31 & 1.31 & 1.31 \\
\hline Metabolizable energy ${ }^{3}$, MJ $\mathrm{kg}^{-1}$ & 13.5 & 13.5 & 13.4 \\
\hline Lys/ME, g.MJ'-1 & 0.55 & 0.55 & 0.55 \\
\hline
\end{tabular}

${ }^{1}$ addition of $2.5 \%$ premix introduce to 1 kg diet: IU: vit. A 1500, vit. $\mathrm{D}_{3}$ 300; mg: Fe 60, Zn 50, Cu 30, Mn 30, J 0.30, Se 0.20, vit. E 150, vit. $\mathrm{K}_{3} 2.0$, vit. $\mathrm{B}_{1} 2.0$, vit. $\mathrm{B}_{2} 2.5$, vit. $\mathrm{B}_{6} 2.0$, vit. $\mathrm{B}_{12} 0.02$, biotin 0.11 , folic acid 0.6 , nicotinic acid 15 , calcium-D pantothenate 10 , choline chloride 500; g: Ca 2.8, P 0.07, and essential amino acids: g: lysine 2.63, methionine 0.68 , threonine 0.98 ; ${ }^{2}$ calculated according to the Degussa (1999); ${ }^{3}$ calculated using RFES (2003) equation

After chilling, the entire Musculus longissimus dorsi from the left half of the carcass was removed and weighed. Each right half-carcass was weighed and next dissected into primal cuts (belly, ham, loin, shoulder, and neck) according to the standardized procedure described by Różycki (1996). Each primal cut was further weighed and dissected into muscle and subcutaneous fat. Next, the entire Musculus longissimus dorsi and subcutaneous fat were ground separately and a random sample of $500 \mathrm{~g}$ was taken from each tissue, homogenized, packed into foil bags, frozen, and kept at $-20^{\circ} \mathrm{C}$ until analysis of the ether extract and fatty acid composition. 


\section{Chemical analysis}

Dry matter, ash, crude protein, ether extract contents in the diets and faeces were determined according to AOAC (1995). Chromic oxide in the diets and faeces was assayed according to the method described by Fenton and Fenton (1979). Metabolizable energy of the diets was calculated according to the following formula:

$$
\begin{gathered}
\mathrm{ME}=(0.0205 \times \mathrm{dBO})+(0.0398 \times \mathrm{dTS})+(0.0173 \times \mathrm{S})+(0.0160 \times \mathrm{C})+(0.0147 \\
\mathrm{x}(\mathrm{dSO}-\mathrm{dBO}-\mathrm{dTS}-\mathrm{S}-\mathrm{C}))
\end{gathered}
$$

where: $\mathrm{dBO}$ - digestible protein; dTS - digestible fat; dSO - digestible organic matter; S - starch; C - simple sugar (RFES, 2003).

Dietary lipids, Musculus longissimus dorsi (MLD), and subcutaneous (ST) fat samples were extracted with chloroform-methanol (2:1) according to the method of Folch et al. (1957). Fatty acid methyl esters were separated by gas chromatography on a GC-2010 AF Schimadzu gas chromatograph equipped with a $60 \mathrm{~m}$ capillary column (BPX70) having a $0.25 \mathrm{~mm}$ inner diameter and coating thickness of $0.25 \mu \mathrm{m}$. The operating conditions were as follows: helium was used as the carrier gas, the split ratio was $1: 100$, injector temperature, $260^{\circ} \mathrm{C}$, detector temperature, $260^{\circ} \mathrm{C}$; the initial column temperature, $140^{\circ} \mathrm{C}$, was held for $1 \mathrm{~min}$, then increased to $200^{\circ} \mathrm{C}$ at a rate of $4^{\circ} \mathrm{C} / \mathrm{min}$, then increased to $220^{\circ} \mathrm{C}$ at a rate of $1{ }^{\circ} \mathrm{C} / \mathrm{min}$. The total run time was $36 \mathrm{~min}$. Individual fatty acid peaks were identified by comparison with a commercial standard, Supelco 37 Component FAME Mix.

\section{Statistical analysis}

Statistical analysis was performed using Statgraphics Centurion (version XV, 2005) software. The effect of diets on the carcass characteristic of pigs was examined with one-way ANOVA. The concentration of fatty acids of subcutaneous and intramuscular fat was analysed using two-way ANOVA with a model that included the fixed effects of diet, tissue, and diet $x$ tissue interaction. The significance of differences between pair-wise combinations of the least squares means was tested. Due to the close relation between animals (litters) and the identical ages of pigs at slaughter, the effect of origin and age of animals was not included in the models.

\section{RESULTS}

The metabolizable energy concentration and digestible protein content in the diets were similar (average13.5 MJ $\mathrm{kg}^{-1}$ and $133 \mathrm{~g} \mathrm{~kg}^{-1}$, respectively) (Table 1). Due to supplementation with different fat mixtures composed of linseed oil, rapeseed oil, and fish oil but varying in their fatty acid (FA) profiles, the diets provided 
different amounts of PUFA (ALA, EPA, and DHA) and different PUFA/SFA and $\mathrm{C} 18: 2 \mathrm{n}-6 / \mathrm{C} 18: 3 \mathrm{n}-3$ ratios. The FA concentration $\left(\mathrm{g} \cdot \mathrm{MJ}^{-1}\right)$ of the diets is shown in Table 2.

Table 2. Fatty acids concentration of the diets, $\mathrm{g} \cdot \mathrm{MJ}^{-1}$

\begin{tabular}{|c|c|c|c|}
\hline \multirow{2}{*}{ Fatty acids } & \multicolumn{3}{|c|}{ Diet $^{1}$} \\
\hline & A & B & $\mathrm{C}$ \\
\hline$\overline{\mathrm{SFA}}$ & 0.71 & 0.55 & 0.71 \\
\hline C14:0 & 0.037 & 0.004 & 0.031 \\
\hline C16:0 & 0.536 & 0.435 & 0.522 \\
\hline C18:0 & 0.097 & 0.077 & 0.122 \\
\hline MUFA & 1.24 & 1.29 & 1.13 \\
\hline C16:1 & 0.058 & 0.006 & 0.047 \\
\hline C18:1 & 1.037 & 1.233 & 0.913 \\
\hline PUFA & 1.75 & 1.83 & 2.14 \\
\hline LA C18:2n-6 & 1.45 & 1.45 & 1.36 \\
\hline ALA $\quad$ C18:3 n-3 & 0.17 & 0.38 & 0.67 \\
\hline AA $\quad$ C $20: 4 n-6$ & 0.001 & 0.000 & 0.000 \\
\hline EPA C20:5 n-3 & 0.052 & 0.000 & 0.044 \\
\hline DPA C22:5 n-3 & 0.009 & 0.000 & 0.007 \\
\hline DHA C22:6 n-3 & 0.069 & 0.000 & 0.057 \\
\hline PUFA/SFA ${ }^{2}$ & 2.48 & 3.30 & 3.01 \\
\hline C18:2 n-6/C18:3n-3 & 8.37 & 3.87 & 2.05 \\
\hline$\sum n-6 / \sum n-3$ & 4.80 & 3.87 & 1.77 \\
\hline
\end{tabular}

${ }^{1}$ see Table 1 ; ${ }^{2}$ PUFA/SFA - the ratio of total polyunsaturated fatty acids (PUFA) to saturated fatty acids (SFA)

Average daily metabolizable energy and apparent digestible lysine intake amounted to $1.23 \mathrm{MJ} \mathrm{ME}$ and $0.68 \mathrm{~g}$ per $\mathrm{kg}^{0.75}$, respectively, and resulted in a daily gain of $960 \mathrm{~g}$ on average for all groups. There were no differences among the groups in daily weight gain. Carcass characteristics are shown in Table 3.

Table 3. Carcass characteristic of pigs, each value is the mean of 8 pigs

\begin{tabular}{|c|c|c|c|c|}
\hline \multirow{2}{*}{ Carcass components } & \multicolumn{3}{|c|}{ Diet $^{1}$} & \multirow{2}{*}{$\mathrm{SE}^{2}$} \\
\hline & A & B & $\mathrm{C}$ & \\
\hline Cold carcass weight, kg & 80.33 & 81.64 & 81.23 & 0.613 \\
\hline Cold carcass (right half) weight, kg & 39.94 & 40.76 & 40.39 & 0.358 \\
\hline Neck & 5.44 & 5.49 & 5.39 & 0.107 \\
\hline Shoulder & 5.53 & 5.83 & 5.67 & 0.078 \\
\hline Loin & 6.72 & 7.08 & 6.67 & 0.087 \\
\hline Belly & 6.84 & 6.95 & 7.07 & 0.087 \\
\hline Ham & 10.20 & 10.24 & 10.18 & 0.137 \\
\hline Subcutaneous fat of the right half carcass, $\mathrm{kg}$ & 4.58 & 4.50 & 4.89 & 0.214 \\
\hline Ether extract of subcutaneous fat, \% & 76.13 & 74.04 & 76.19 & 0.807 \\
\hline Musculus longissimus dorsi, kg & 2.34 & 2.56 & 2.33 & 0.042 \\
\hline Ether extract of MLD, \% & 3.35 & 2.92 & 3.40 & 0.230 \\
\hline Meat from the right half of the carcass, kg & 24.56 & 25.16 & 24.70 & 0.281 \\
\hline Meat content in carcass, \% & 61.49 & 61.73 & 61.17 & 0.575 \\
\hline
\end{tabular}

${ }^{1}$ see Table $1 ;{ }^{2} \mathrm{SE}$ - standard error of a mean 
Different fat mixtures in the diets had no effect on whole carcass, primal cuts, subcutaneous adipose tissue, or MLD weight as well as meat and total fat content in the carcass.

The FA composition in the intramuscular fat of Musculus longissimus dorsi and subcutaneous fat is shown in Table 4.

Table 4. Total fatty acid composition of intramuscular and subcutaneous tissue fat

\begin{tabular}{|c|c|c|c|c|c|c|c|}
\hline \multirow{3}{*}{$\begin{array}{l}\text { Fatty acids, \% of } \\
\text { total fatty acids }\end{array}$} & \multirow{2}{*}{ Diet $^{1}$} & \multicolumn{2}{|c|}{ Tissue } & \multirow{2}{*}{$\mathrm{SE}^{2}$} & \multicolumn{3}{|c|}{ Significance } \\
\hline & & MLD & ST & & diet & tissue & diet $\mathrm{x}$ tissue \\
\hline & $\mathrm{A}$ & 20.17 & 20.07 & & & & \\
\hline \multirow{2}{*}{$\mathrm{C} 16: 0$} & B & 19.85 & 18.75 & 0.449 & NS & NS & NS \\
\hline & $\mathrm{C}$ & 21.02 & 18.67 & & & & \\
\hline \multirow[t]{3}{*}{ C16:1 n-7 } & A & 2.42 & 1.47 & & & & \\
\hline & B & 2.06 & 1.25 & 0.065 & 0.081 & 0.000 & NS \\
\hline & $\mathrm{C}$ & 2.36 & 1.40 & & & & \\
\hline \multirow[t]{3}{*}{ C18:0 } & A & 13.92 & 13.96 & & & & \\
\hline & B & 13.62 & 12.80 & 0.376 & 0.065 & NS & NS \\
\hline & $\mathrm{C}$ & 15.69 & 13.54 & & & & \\
\hline \multirow[t]{3}{*}{ C18:1 n-9 } & A & 36.50 & 37.65 & & & & \\
\hline & B & 37.01 & 38.65 & 0.439 & 0.067 & NS & NS \\
\hline & $\mathrm{C}$ & 35.01 & 36.39 & & & & \\
\hline \multirow[t]{3}{*}{ C18:2 n-6 } & A & 10.55 & 18.76 & & & & \\
\hline & B & 11.20 & 20.00 & 0.376 & 0.030 & 0.000 & NS \\
\hline & $\mathrm{C}$ & 11.65 & 19.86 & & & & \\
\hline \multirow[t]{3}{*}{$\mathrm{C} 18: 3 \mathrm{n}-3$} & A & 0.88 & 1.70 & & & & \\
\hline & B & 1.46 & 3.01 & 0.096 & 0.000 & 0.000 & 0.000 \\
\hline & $\mathrm{C}$ & 2.06 & 4.60 & & & & \\
\hline \multirow[t]{3}{*}{ C20:4 n-6 } & A & 0.76 & 0.12 & & & & \\
\hline & B & 0.70 & 0.11 & 0.028 & NS & 0.000 & NS \\
\hline & $\mathrm{C}$ & 0.84 & 0.08 & & & & \\
\hline \multirow[t]{3}{*}{ C20:5 n-3 } & A & 0.54 & 0.09 & & & & \\
\hline & B & 0.58 & 0.03 & 0.020 & NS & 0.000 & NS \\
\hline & C & 0.53 & 0.10 & & & & \\
\hline \multirow[t]{3}{*}{ C22:5 n-3 } & A & 0.72 & 0.13 & & & & \\
\hline & B & 0.77 & 0.07 & 0.027 & NS & 0.000 & NS \\
\hline & C & 0.70 & 0.16 & & & & \\
\hline \multirow[t]{3}{*}{ C22:6 n-3 } & A & 0.42 & 0.15 & & & & \\
\hline & B & 0.36 & 0.03 & 0.023 & NS & 0.000 & NS \\
\hline & C & 0.30 & 0.17 & & & & \\
\hline \multirow[t]{3}{*}{ SFA } & A & 36.36 & 35.15 & & & & \\
\hline & B & 35.39 & 32.53 & 0.482 & NS & 0.002 & 0.055 \\
\hline & C & 39.17 & 33.21 & & & & \\
\hline \multirow[t]{3}{*}{ MUFA } & A & 42.17 & 41.51 & & & & \\
\hline & B & 42.14 & 41.91 & 0.464 & 0.075 & NS & NS \\
\hline & C & 40.71 & 39.97 & & & & \\
\hline
\end{tabular}


Table 1. Continued

\begin{tabular}{|c|c|c|c|c|c|c|c|}
\hline \multirow{2}{*}{$\begin{array}{l}\text { Fatty acids, \% of } \\
\text { total fatty acids }\end{array}$} & \multirow{2}{*}{ Diet $^{1}$} & \multicolumn{2}{|c|}{ Tissue } & \multirow{2}{*}{$\mathrm{SE}^{2}$} & \multicolumn{3}{|c|}{ Significance } \\
\hline & & MLD & ST & & diet & tissue & diet $\mathrm{x}$ tissue \\
\hline PUFA & $\begin{array}{l}\text { A } \\
\text { B } \\
\text { C }\end{array}$ & $\begin{array}{l}13.87 \\
14.90 \\
16.09\end{array}$ & $\begin{array}{l}21.42 \\
23.95 \\
25.59\end{array}$ & 0.430 & 0.003 & 0.000 & NS \\
\hline PUFA/SFA ${ }^{3}$ & $\begin{array}{l}\text { A } \\
\text { B } \\
\text { C }\end{array}$ & $\begin{array}{l}0.38 \\
0.42 \\
0.41\end{array}$ & $\begin{array}{l}0.61 \\
0.74 \\
0.77\end{array}$ & 0.015 & 0.012 & 0.000 & 0.030 \\
\hline $\begin{array}{l}\text { C18:2 n-6/ C18:3 } \\
n-3\end{array}$ & $\begin{array}{l}\text { A } \\
\text { B } \\
\text { C }\end{array}$ & $\begin{array}{r}12.53 \\
7.95 \\
5.87\end{array}$ & $\begin{array}{r}11.21 \\
6.68 \\
4.46\end{array}$ & 0.292 & 0.000 & 0.008 & NS \\
\hline$\sum n-6 / \sum n-3$ & $\begin{array}{l}\text { A } \\
\text { B } \\
\text { C }\end{array}$ & $\begin{array}{l}4.45 \\
3.82 \\
3.51\end{array}$ & $\begin{array}{l}9.00 \\
6.18 \\
3.99\end{array}$ & 0.132 & 0.000 & 0.000 & 0.000 \\
\hline
\end{tabular}

$\overline{{ }^{1} \text { see Table } 1 ;{ }^{2} \mathrm{SE} \text { - standard error of a mean; }{ }^{3} \mathrm{PUFA} / \mathrm{SFA} \text { - the ratio of total polyunsaturated }}$ fatty acids (PUFA) to saturated fatty acids (SFA); ${ }^{\mathrm{a}, \mathrm{b}}$ means within the same line with no common superscripts differ at $\mathrm{P}<0.05$; ${ }^{\mathrm{A}, \mathrm{B}}$ means within the same line with no common superscripts differ at $\mathrm{P}<0.01$; NS - not significant

The diets influenced the concentration of PUFA, which was higher $(\mathrm{P}<0.01)$ in pigs fed diets B and C (average 20.14\%) than in the animals fed diet A (17.64\%). These results are related to the concentrations of LA and ALA. The concentration of LA was higher in pigs fed diets $B$ and $C$ compared with those fed diet A (average 15.68 vs $14.66 \% ; \mathrm{P}<0.05)$. The concentration of ALA was, however, the highest in animals fed diet $\mathrm{C}$, lower in those fed diet $\mathrm{B}$, and the lowest in pigs fed $\operatorname{diet} \mathrm{A}$ (3.33, 2.23, and 1.29, respectively; $\mathrm{P}<0.01$ ). The PUFA/SFA ratio also was higher $(\mathrm{P}<0.05)$ in pigs fed diets B and $\mathrm{C}$ (average 0.59) than in those fed $\operatorname{diet} \mathrm{A}(0.49)$. The ratio of $C 18: 2$ n-6/C18:3 n-3 was much lower in pigs fed diet $C$, higher in those fed diet B, and the highest in animals fed diet A (5.16, 7.32, and 11.87; respectively; $\mathrm{P}<0.01)$. When the ratio of total n-6 PUFA $/ n-3$ PUFA( $(\Sigma n-6 / \Sigma n-3)$ was taken into consideration, however, it was the highest in pigs fed diet $\mathrm{A}$, lower in those fed diet $\mathrm{B}$, and the lowest in animals fed diet $\mathrm{C}(6.73,5.00$, and 3.75; respectively; $\mathrm{P}<0.01)$. The concentrations of the remaining FA were not affected by the feeds.

The type of tissue, muscle (MLD) and fat (ST), influenced the fatty acid profile. In MLD fat, the concentration of SFA was higher compared with ST fat (average 36.98 vs $33.63 \%$, respectively; $\mathrm{P}<0.01$ ). The concentration of total MUFA did not differ between tissues, however, the content of palmitoleic acid (C16:1 n-7) in MLD fat was higher $(\mathrm{P}<0.01)$ than in ST fat $(2.28$ vs $1.37 \%$, respectively). The concentration of PUFA was higher $(\mathrm{P}<0.01)$ in ST fat compared with MLD fat (average 23.66 vs $14.95 \%$, respectively). The concentrations of LA and ALA were higher $(\mathrm{P}<0.01)$ in ST fat than in MLD fat (average 19.54 and $3.10 \%$ vs 11.13 and $1.47 \%$, respectively). The concentrations of EPA, DPA and DHA, however, were 
higher $(\mathrm{P}<0.01)$ in MLD fat compared with ST fat (average $0.55,0.73$, and $0.36 \%$ vs $0.07,0.12$, and $0.11 \%$, respectively). MLD fat contained a higher $(\mathrm{P}<0.01)$ concentration of arachidonic (AA, 20:4 n-6) acid than ST fat (average 0.77 vs $0.11 \%$, respectively). The ratio of PUFA/SFA was greater $(\mathrm{P}<0.01)$, however, in ST fat than in MLD fat (average 0.71 vs 0.40, respectively), but that of C18:2 n-6/ C18:3 n-3 was lower $(\mathrm{P}<0.01)$ in ST fat than in MLD fat (average 7.45 vs 8.78, respectively), and the $\Sigma \mathrm{n}-6 / \Sigma \mathrm{n}-3$ ratio was lower $(\mathrm{P}<0.01)$ in MLD fat compared with ST fat (average 3.93 vs 6.39 , respectively).

Moreover, significant interactions between experimental treatments were found for the following investigated features: the concentration of $\mathrm{C} 18: 3 \mathrm{n}-3$ $(\mathrm{P}<0.01)$, PUFA/SFA $(\mathrm{P}<0.03)$ and $\sum \mathrm{n}-6 / \sum \mathrm{n}-3(\mathrm{P}<0.01)$ ratios.

\section{DISCUSSION}

The fat mixtures used in the study did not influence the growth rate or feed conversion ratio due to the same energetic, nutritive value and feeding regime ( $85 \%$ of ad libitum). These results are in agreement with previous studies (e.g., Nguyen et al., 2003).

According to our assumptions, replacing part of the energy of the basal diet by different fat mixtures also did not influence meat or subcutaneous fat content in the carcass. The fat mixtures had no effect on other slaughtering parameters (e.g., meat content), either.

The results of our study and also those carried out by other authors (e.g., Kouba et al., 2003; Flachowsky et al., 2008; Wood et al., 2008) confirm that it is possible to change the content of FA and the relation between fatty acids belonging to the n- 6 and $n-3$ series in pig tissues by applying an appropriate source of fat in the diet. In our study, the supplemented mixtures of fat showed significant effects on all fatty acids in the tissues. Higher concentrations of fatty acids in the diet resulted in a higher percentage of specific fatty acids in tissues. Pigs fed the diet supplemented with linseed oil and fish oil increased the concentration of n-3 PUFA, particularly C18:3 n-3 in their tissues, those fed the diet with rapeseed oil and fish oil had increased C18:2 n-6 and n-3 PUFA concentrations in their tissues.

Furthermore, all of these vegetable oils reduced the ratio of PUFA/SFA and $\Sigma \mathrm{n}-6 / \Sigma \mathrm{n}-3$ in the investigated tissues, but to different degrees, which was dependent on the n-3 PUFA content in the tissues. Our results are in agreement with other studies (e.g., Bryhni et al., 2002; Flachowsky et al. al., 2008; Wood et al., 2008; Guillevic et al., 2009; Skiba et al., 2011).

The results of our experiment show that the diet containing linseed oil and fish oil, having the highest concentration of n-3 PUFA, had the most favourable influence on the fatty acid profile and on the PUFA/SFA and $\Sigma n-6 / \Sigma n-3$ ratios. 
The use of this diet makes it possible to obtain pork characterized by good quality and health-promoting properties. Moreover, meat and fat from pigs fed this diet achieved values most similar to the WHO recommendations. In our previous studies we also found significant differences between the ratio of PUFA/SFA and $\Sigma \mathrm{n}-6 / \Sigma \mathrm{n}-3$ in the tissues of pigs of different breeds fed diets supplemented with a single oil (Raj et al., 2010; Skiba et al., 2011). In these studies we found the most preferable ratio of PUFA/SFA in the subcutaneous fat of pigs restrictively fed a diet containing linseed oil, as compared with pigs fed diets supplemented with rapeseed or fish oils. We found the lowest ratio of PUFA/SFA in the tissues of pigs fed a diet supplemented with tallow. Raj et al. (2010) found differences in fatty acid profiles of breeds when pigs were fed the same diet ad libitum. De Smet et al. (2004) found that the ratio of PUFA/SFA is first of all influenced by genetics (mainly the overall fat level of the animal and intramuscular fat content) and less by nutrition. Furthermore, in the presented study we found that the $\Sigma n-6 / \Sigma n-3$ ratio is highly influenced by the composition of dietary fatty acids, as the lowest value of this ratio was in pigs fed the diet containing the highest concentration of n-3 PUFA. Pigs fed a diet with the moderate and the lowest concentrations of this group of fatty acids had worse $\Sigma \mathrm{n}-6 / \Sigma \mathrm{n}-3$ ratio than recommended by the WHO. Moreover, we found that it is better to modify the fatty acid composition of pig tissues by using mixtures of fats than single oils (Raj et al., 2010; Skiba et al., 2011). Similar results have been found by other authors (e.g., Nguyen et al., 2003; Więcek et al., 2010).

Diets did not affect the content of SFA, MUFA, or LA in the intramuscular fat of the Longissimus dorsi muscle and subcutaneous fat. Both of these tissues differed significantly, however, in the content of omega-3 (n-3) fatty acids. The diet that most improved the content of these acids contained a mixture of linseed and fish oils. For this reason, tissues of pigs fed this diet also had significantly improved PUFA/SFA and $\Sigma$ n- $6 / \Sigma$ n-3 ratios. These indicators fulfilled the requirements for health-promoting properties of pork.

We found more preferable PUFA/SFA and $\Sigma \mathrm{n}-6 / \Sigma \mathrm{n}-3$ ratios in the intramuscular fat of Longissimus dorsi than in the subcutaneous fat. This suggests that the composition of fatty acids may vary depending on the type of investigated tissues. Our suggestions are in agreement with the conclusions of other authors (e.g., Raes et al., 2004; Skiba et al., 2011).

Moreover, we found differences between the investigated tissues in the concentrations of n-6 PUFA and n-3 PUFA. In the intramuscular fat, the concentration of EPA, DPA, and DHA increased more intensively than in the subcutaneous fat, even though the concentrations of LA and ALA were significantly higher in the subcutaneous tissue than in the intramuscular fat of the Longissimus dorsi muscle. Similar relations have been confirmed by other authors, including 
Kouba et al. (2003), Nguyen et al. (2003), Guillevic et al. (2009), Raj et al. (2010), and Skiba et al. (2011). Tissue differences in the concentrations of LA and ALA can be partly explained by the different levels of incorporation of these fatty acids into tissues. Based on a regression coefficient, Nguyen et al. (2003) found that the yield of deposition of LA is smaller for intramuscular fat than for adipose tissue. This points to the preferential incorporation of LA into adipose tissue. The same author concluded that ALA is more efficiently incorporated into intramuscular fat than into adipose tissue.

In the current study, we found a higher concentration of SFA (especially palmitic acid) and MUFA (especially palmitoleic acid) in MLD fat than in ST fat. Similar differences between tissues were presented by Lebret and Mourot (1998). These authors also claimed that an increase in the lipid content may be desirable for certain tissues (e.g., intramuscular fat) and much less for other tissues (e.g., leaf fat).

Similar responses of animals to supplementation of diets with diverse sources of fatty acids with regard to the proportions of SFA, MUFA, and PUFA in the muscle and adipose tissue were also found by Kouba et al. (2003), Kloareg et al. (2007), Wood et al. (2008), and Guillevic et al. (2009).

In our study, a significant interaction was detected between diets and tissues in the ALA concentration and PUFA/SFA and $\Sigma \mathrm{n}-6 / \Sigma \mathrm{n}-3$ ratios. The ALA concentration was of a similar order in both tissues and was the lowest in pigs fed the diet supplemented with the mixture of rapeseed oil and fish oil, and the highest in animals fed the diet containing linseed oil and fish oil. Inversely, the $\Sigma n-6 / \Sigma n-3$ ratio was the highest in pigs fed the diet supplemented with the mixture of rapeseed oil and fish oil, and the lowest in animals fed the diet containing linseed and fish oils. The PUFA/SFA ratio was the lowest in animals fed the diet supplemented with the mixture of rapeseed oil and fish oil, and similar in the remaining groups. Both tissues responded similarly to the diets supplemented with various fat sources, but the changes were much more evidenced in the subcutaneous tissue.

These results can be explained by the different yields of LA and ALA accumulation in fat and muscle tissues, which is in agreement with the data presented by Enser et al. (1996), Nguyen et al. (2003), Kloareg et al. (2007), and Wood et al. (2008). Some fatty acids are preferentially deposited in certain tissues (Nguyen et al., 2003). Another reason for such a response of our pigs could be that the content of ether extract in Musculus longissimus dorsi and subcutaneous fat. The latter tissue is characterized by a higher content of ether extract, thus LA and ALA can be more easily incorporated into subcutaneous fat. Moreover, Kloareg et al. (2007) claimed that the profiles of fatty acids and the yield of accumulation of fatty acids in tissues change during growth. Our groups of pigs were compared at the same growth stage, so age could not have influenced the investigated features. 


\section{CONCLUSIONS}

Based on the results of our study it can be concluded that the fatty acid composition of the subcutaneous and intramuscular fat of pigs is related to the fatty acid concentration in the diet. Moreover, these relations were more evident in subcutaneous fat than in intramuscular fat. At the same content of lnoleic acid, the diet rich in omega-3 fatty acids containing a mixture of linseed oil and fish oil makes it possible to obtain the most beneficial ratios of PUFA/SFA and n-6/n-3 in pig carcasses. Thus, this diet could be useful in producing good quality pork with health-promoting properties.

\section{REFERENCES}

AOAC, 1995. Association of Official Analytical Chemists, Official Methods of Analysis. $16^{\text {th }}$ Edition. Arlington, VA

Bryhni E.A., Kjos N.P., Ofstad R., Hunt M., 2002. Polyunsaturated fat and fish oil in diets for growing-finishing pigs: effects on fatty acid composition and meat, fat, and sausage quality. Meat Sci. 62, 1-8

Degussa, 1999. Standardized Ileal Digestibility of Amino Acids in Pigs. Degussa AG. Frankfurt am Main (Germany)

De Smet S., Raes K., Demeyer D., 2004. Meat fatty acid composition as affected by fatness and genetic factors: a riview. Anim. Res. 53, 81-98

Enser M., Hallett K., Hewitt B., Fursey G.A.J., Wood J.D., 1996. Fatty acid content and composition of Engish beef, lamb and pork at retail. Meat Sci. 42, 443-456

Fenton T.W., Fenton M., 1979. An improved procedure for the determination of chromic oxide in feed and faeces. Can. J. Anim. Sci. 59, 631-634

Flachowsky G., Schulz E., Kratz R., Glodek P., 2008. Effect of different dietary fat sources on the fatty acid profile of backfat and intramuscular fat of pigs of various sire breeds. J. Anim. Feed Sci. 17, 363-371

Folch J., Lees M., Stanley G.H.S., 1957. A simple method for the isolation and purification of lipids from animal tissues. J. Biol. Chem. 226, 497-509

Guillevic M., Kouba M., Mourot J., 2009. Effect of a linseed diet or a sunflower diet on performances, fatty acid composition, lipogenic enzyme activities and steroyl-CoA-desaturase activity in the pig. Livest. Sci. 124, 288-294

Heird W.C., Lapillonne A., 2005. The role of essential fatty acids in development. Annu. Rev. Nutr. 25, 23.1-23.23

Jaturasitha S., Khiaosa-ard R., Pongpiachan P., Kreuzer M., 2009. Early deposition of n-3 fatty acids from tuna oil in lean and adipose tissue of fattening pigs is mainly permanent. J. Anim. Sci. 87, 693-703

Kloareg M., Noblet J., Milgen J., 2007. Deposition of dietary fatty acids, de novo synthesis and anatomical partitioning of fatty acids in finishing pigs. Brit. J. Nutr. 97, 35-44

Kouba M., Enser M., Whittington F.M., Nute G.R., Wood J.D., 2003. Effect of a high-linolenic acid diet on lipogenic enzyme activities, fatty acid composition, and meat quality in the growing pig. J. Anim. Sci. 81, 1967-1979 
Laaksonen D.E., Nyyssönen K., Niskanen L., Rissanen T.H., Salonen J.T., 2005. Prediction of cardiovascular mortality in middle-age men by dietary and serum linoleic and polyunsaturated fatty acids. Arch. Intern. Med. 165, 193-199

Lebret B., Mourot J., 1998. Caractéristiques et qualité des tissus adipeax chez le proc. Facteurs de variation non génétiques. INRA Prod. Anim. 11, 131-143

Nguyen L.Q., Nuijens M.C.G.A., Everts H., Salden N., Beynen A.C., 2003. Mathematical relationship between the intake of n-6 and n-3 polyunsaturated fatty acids and their contents in adipose tissue of growing pigs. Meat Sci. 65, 1399-1406

Raes K., De Smet S., Demeyer D., 2004. Effect of dietary fatty acids on incorporation of long chain polyunsaturated fatty acids and conjugated linoleic acid in lamb, beef and pork meat: a review. Anim. Feed Sci. Tech. 113, 199-221

Raj S., Skiba G., Weremko D., Fandrejewski H., Migdał W., Borowiec F., Poławska E., 2010. The relationship between the chemical composition of the carcass and the fatty acid composition of intramuscular fat and backfat of several pig breeds slaughtered at different weights. Meat Sci. 86, 324-330

RFES, Rostock Feed Evaluation System, 2003. Reference numbers of feed value and requirement on the base of net energy. W. Jentsch, A.Chudy, M. Beyer (Editors). FBN, WGL, Oskar Kellner. Dummerstorf (Germany)

Różycki M., 1996. Rules at evaluating the pigs in Pig Slaughter Testing Station. In: State of Pig Breeding and Pig Evaluation Results (in Polish). National Research Institute of Animal Production, Kraków, pp. 69-82

Skiba G., Poławska E., Raj S., Weremko D., Czauderna M., Wojtasik M., 2011. The influence of dietary fatty acids on their metabolism in liver and subcutaneous fat in growing pigs. J. Anim. Feed Sci. 20, 379-388

WHO/FAO, 2003. Diet Nutrition and the Prevent of Chronic Diseases. Report of a Joint WHO/FAO Expert Consultation. WHO Technical Report Series 916. Geneva

Więcek J., Rekiel A., Skomiał J., 2010. Effect of feeding level and linseed oil on some metabolic and hormonal parameters and on fatty acid profile of meat and fat in growing pigs. Arch. Anim. Nutr. 53, 37-49

Wood J.D., Enser M., Fisher A.V., Nute G.R., Sheard P.R., Richardson R.I., Hughes S.I., Whittington F.M., 2008. Fat deposition, fatty acid composition and meat quality: A review. Meat Sci. 78, 343-358 